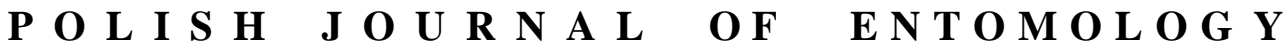

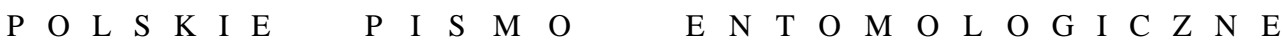

VOL. 86: 237-250

Lublin

30 September 2017

DOI: $10.1515 /$ pjen-2017-0014

\section{Potential of seed dusts of Jatropha curcas L., Thevetia peruviana (PERS.), and Piper guineense SCHUMACH. against the maize weevil, Sitophilus zeamais (MoTSCHULSKY, 1855) (Coleoptera: Curculionidae) in storage of corn grain}

\author{
ONINYE M. UKPAI, BRIANDAVIS N. IBEDIUNGHA, COLLINS N. EHISIANYA* \\ Department of Zoology and Environmental Biology, Michael Okpara University \\ of Agriculture, Umudike, P.M.B. 7267, Umuahia, Abia State, Nigeria
}

\begin{abstract}
A laboratory evaluation was carried out to determine the efficacy and phytochemical composition of powdered seeds of Physic nut Jatropha curcas, Yellow oleander Thevetia peruviana and West African black pepper Piper guineense at different dosages (2.5, 5.0, 7.5 and $10.0 \mathrm{~g}$ ) for the management of Sitophilus zeamais. Treatments were mixed with $50 \mathrm{~g}$ of maize and infested with 10 adult $S$. zeamais in $200 \mathrm{ml}$ air-tight glass vials and kept under ambient conditions $\left(25-30^{\circ} \mathrm{C}\right.$ and $\left.70-90 \mathrm{RH}\right)$ for a period of 28 days in August 2015. The trial was laid out in a completely randomized design in four replicates. Results from data analyses showed that treated maize grains in storage recorded significantly $(\mathrm{P}<0.05)$ higher mean mortality levels of adult $S$. zeamais than the untreated controls. However, there were no significant differences in mean mortality of the weevil at 7, 14, 21 and 28 DAT, except on those stored only for 1 DAT. Batches treated with higher doses $(10.0,7.5,5.0 \mathrm{~g})$ suffered a higher total mortality of adult $S$. zeamais; this was significantly $(\mathrm{P}<0.05)$ higher compared with treatments using smaller dosages $(2.5$ and $0.0 \mathrm{~g})$. Phytochemical analysis of treatments revealed high levels of alkaloids, tannins and phenols in all the plant extracts. The flavonoid contents were also high in Piper guineense and Permethrin, but lower in Jatropha curcas and Thevetia peruviana. These compounds are known to possess insecticidal properties that may have been responsible for the mortality of Sitophilus zeamais.
\end{abstract}

KEY WORDS: Botanicals, efficacy, phytochemical, Sitophilus zeamais.

\footnotetext{
*Corresponding author: cnehisianya@gmail.com
} 


\section{INTRODUCTION}

Maize (Zea mays L.) is an important staple cereal crop for most people in sub-Saharan Africa (NUKENINE et al. 2002). Besides being a major source of food for both human and animals worldwide, it is also processed into various industrial products such as fuel (ethanol) and starches (OGUNSINA et al. 2011).

In the past, the efficacy of a particular pest control measure was the most important consideration to all stakeholders in the grain value-chain, but at present, the safety of workers, effects on the environment and product quality are issues of high priority. The bulk of African grains come from small-scale farmers' holdings. These traditional farmers use different kinds of plant products to control pests. The precise strategy used by different communities varies from place to place and appears to depend partly on the type and efficacy of suitable materials available in different locations (GREENBERG et al. 2005). Many African plants are potential sources of pesticides and have been shown to contain either anti-feedant, repellent or insecticidal compounds that enable the crude plant material or an extracted active compound to protect stored products (KUBO \& NAKANISHI 1977). If sufficiently exploited, botanical pesticides can play a big role in reducing pollution, health risks and crop losses to pests (KAMATENESI-MUGISHA et al. 2008).

LALE (2010) observed that insect pests of grains can seldom be separated from their grains. The presence of Sitophilus zeamais (MOTSCHULSKY, 1855) has been established in the maize seed (LALE 2002, OBENG-OFORI \& AMiteye 2005, Danloye et al. 2008). In most of Africa, the greater proportion of maize is produced by resource-poor farmers in remote villages with poor road networks and poor post-harvest storage facilities, which often results in their incurring substantial losses (NTONIFOR \& MONAH 2001). ISLAM (2006) estimated grain loss in Africa due to insect pest damage in storage at 20 to $30 \%$. According to NUKENINE et al. (2002), S. zeamais causes more than $20 \%$ grain loss for untreated maize worldwide. Storage ensures food availability and security, profit maximization and seed availability for the next planting season.

In Nigeria, synthetic insecticides such as Lindane, methyl-bromide iodofenphos, malathion, permethrin, actellic sumithion, whose modes of action are broad-spectrum, have been marketed under different trade names to control stored-product pests. Farmers, produce-merchants and housewives store food grains with these insecticides in various facilities. The use of synthetic insecticides has been reported to leave residues (TOTEJA et al. 2006, UYGUN et al. 2007). A variety of botanicals such as Jatropha curcas L., Thevetia peruviana (L.) LIPPOLD, Piper guineense SCHUMACH. and Carica papaya L. are being used by resource-poor farmers in different parts of Nigeria (GADZIRAYI et al. 2006), but information on their efficacy against Sitophilus zeamais on stored maize in view of the crop's economic importance is scarce. The objectives of this study were therefore to 
determine the effectiveness and phytochemical composition of these botanicals for the control of $S$. zeamais, which is a major pest of stored maize.

\section{MATERIALS AND METHODS}

The experiment was conducted in August 2015 to determine the efficacy of selected botanicals (Jatropha curcas, Thevetia peruviana and Piper guineense) to control Sitophilus zeamais at the Post-Graduate Laboratory of the Department of Zoology and Environmental Biology, Michael Okpara University of Agriculture, Umudike (latitude $05^{\circ} 26^{\prime}$ to $5^{\circ} 25^{\prime} \mathrm{N}$ and longitude $07^{\circ} 34^{\prime}$ to $7^{\circ} 36^{\prime}$ E), Abia State, Nigeria.

\section{Insect Culture}

The adult $S$. zeamais used for the experiment were cultured in plastic buckets covered with muslin cloth in the laboratory at $27 \pm 2{ }^{\circ} \mathrm{C}, 60$ to $65 \%$ relative humidity and $12 \mathrm{~h}: 12 \mathrm{~h}$ light: dark regime. S. zeamais were obtained from infested stocks of maize from small scale farmers at Umuokrika Ekwerazu, Ahiazu Mbaise, Imo State. The S. zeamais used were reared for six weeks; only adults were used for this study.

\section{Maize Used for the Experiment}

The Zea mays used for the experiment was purchased from Ndoro market at Ikwuano L.G.A of Abia State. A pre-experiment was conducted to ascertain whether the maize was free from chemicals to avoid altering the results in the laboratory for 28 days. No mortality indicated that the maize grains were free from chemicals before use. Furthermore, the grains were heated in an oven at $60{ }^{\circ} \mathrm{C}$ for 4 hrs to destroy any hidden infestation and then maintained at ambient temperature and relative humidity.

\section{Preparation of the Botanic Dusts}

Two hundred grams of mature fresh seeds of the botanicals were collected from Umuokrika Ekwerazu and Amawom at Ikwuano L.G.A, Abia State. The seeds were sundried, ground separately into powder with a hand grinder and then sieved to obtain fine powders. The powders were put into dark air-tight containers to ensure that their active ingredients were not lost, and stored in a cool dry place until needed.

\section{Synthetic Insecticide Used}

The synthetic insecticide (Permethrin) used for the experiment was bought from a chemical dealer in Umuahia. 


\section{Methodology}

The treatments, i.e. Jatropha curcas, Thevetia peruviana and Piper guineense (Table 1), the check (Permethrin) of different dosages (2.5, 5.0, 7.5 and $10.0 \mathrm{~g}$ ), and an untreated control were tested against Sitophilus zeamais in stored maize. Each treatment dosage was mixed with $50 \mathrm{~g}$ of pristine maize grain and shaken thoroughly by agitating the vials manually. $1 \mathrm{~g}$ of talcum powder was also added to increase adhesion (binding) and treatment efficacy. The Completely Randomized Design (CRD) was adopted for the experiment and each treatment was replicated four times.

Table 1. Tested plant products, part used and their bioactive compounds.

\begin{tabular}{|l|l|l|l|}
\hline \multicolumn{1}{|c|}{ Tested plant products } & Part used & Bioactive compounds & \multicolumn{1}{c|}{ References } \\
\hline $\begin{array}{l}\text { Piper guineense } \\
\text { West African black Pepper }\end{array}$ & Seed & Piperine & LALE \& ALAGA (2000) \\
\hline $\begin{array}{l}\text { Jatropha curcas } \\
\text { Physic nut }\end{array}$ & Seed & Phorbol esters (PEs) & $\begin{array}{l}\text { MARTINEZ-HERRERA et al. } \\
(2004), \text { GOEL et al, (2007) }\end{array}$ \\
\hline $\begin{array}{l}\text { Thevetia peruviana } \\
\text { Yellow oleander }\end{array}$ & Seed & Unknown & - \\
\hline
\end{tabular}

Ten unsexed adults of Sitophilus zeamais were introduced into each vial and covered with muslin cloth held tightly in place by a rubber band to prevent the insects from escaping and/or predators entering.

Using the method reported by OMOTOSO (2014), the mortality counts of the weevils were recorded at 1, 7, 14, 21 and 28 days after treatment (DAT). The numbers of dead insects (insects which did not respond to pin probes) were recorded and removed from all the experimental vials. The counting was done by pouring the contents of each vial onto a small white tray and sorting the dead insects using a camel-hair brush and pin probe.

\section{Phytochemical Analysis of the Plant Extract and the Synthetic Insecticides}

The botanicals and Permethrin dust were extracted using ethanol, then subjected to preliminary screenings for the presence of secondary metabolites (alkaloids, tannins, flavonoids, phenols and saponins) using standard procedures (TREASE \& EVANS 1989) with some modifications.

\section{Test for Alkaloids}

To test for alkaloids, $5 \mathrm{ml}$ of $2 \% \mathrm{HCl}$ was added to $2 \mathrm{ml}$ of each of the samples in a test tube placed on a steam bath and warmed. This was filtered and a few drops of Wagner's Reagent (potassium iodide + iodine solution) were added to the filtrate in a test tube. The 
observed reddish brown precipitate indicated the presence of alkaloids (NWOKOCHA et al. 2011).

\section{Test for Tannins}

To test for tannins, $5 \mathrm{ml}$ of each of the samples were treated with $2 \mathrm{ml}$ of $\mathrm{HCl}$ and boiled for 5 minutes. A red precipitate confirmed the presence of tannins (NWOKOCHA et al. 2011).

\section{Test for Flavonoids}

To test for flavonoids, $1 \mathrm{ml}$ of each of the samples was treated with $1 \mathrm{ml}$ of dilute $\mathrm{NaOH}$. A cloudy precipitate confirmed the presence of flavonoids (NwOKOCHA et al. 2011).

\section{Test for Saponins}

To test for saponins, $1 \mathrm{ml}$ of each of the samples was added to $4 \mathrm{ml}$ of distilled water and shaken. A stable frothing of foam indicated the presence of saponins (NWOKOCHA et al. 2011).

\section{Test for Phenols}

To test for phenols, $1 \mathrm{ml}$ of each of the samples was added to $1 \mathrm{ml}$ of $10 \% \mathrm{FeCl}$ and mixed. A blue precipitate confirmed the presence of phenols (NwOKOCHA et al. 2011).

\section{Data Analysis}

Count data such as numbers of dead adult Sitophilus zeamais were transformed to square root values to improve the normality of the variable (variance stability), after which two-way analysis of variance was applied to compare means. Significant means were separated using the SNK test at a 5\% error limit using SAS software version 8(2) (SAS 2001).

\section{RESULTS}

Effect of treatments on mean total mortality of Sitophilus zeamais in stored maize

Treated maize grains in storage caused significantly higher mean mortality than the untreated control (Fig. 1). Mean mortality at all treatment doses was higher with Permethrin and Piper guineense than with Jatropha curcas and Thevetia peruviana, although the differences were not significant.

There were no significant differences in mean adult mortality of treated maize grains stored at 7, 14, 21 and 28 DAT, except for those stored only for 1 DAT. Similarly, the 
treatments tested were not significantly different from each other, except for the batches treated with $T$. peruviana, where mean mortality increased significantly from 7 DAT (2.35) to 14 DAT (2.58) but decreased significantly at 21 DAT (2.14) (Fig. 2).

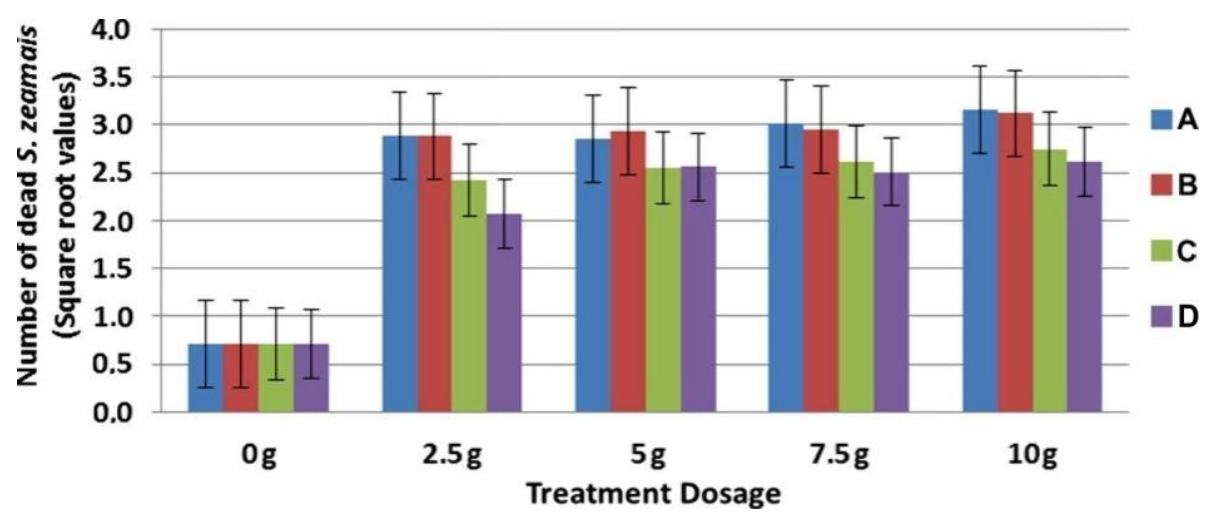

Fig. 1. Mean mortality of Sitophilus zeamais treated with different doses of botanicals. A - Permethrin, B - Piper guineense, C - Jatropha CURCAS, D - Thevetia peruviana.

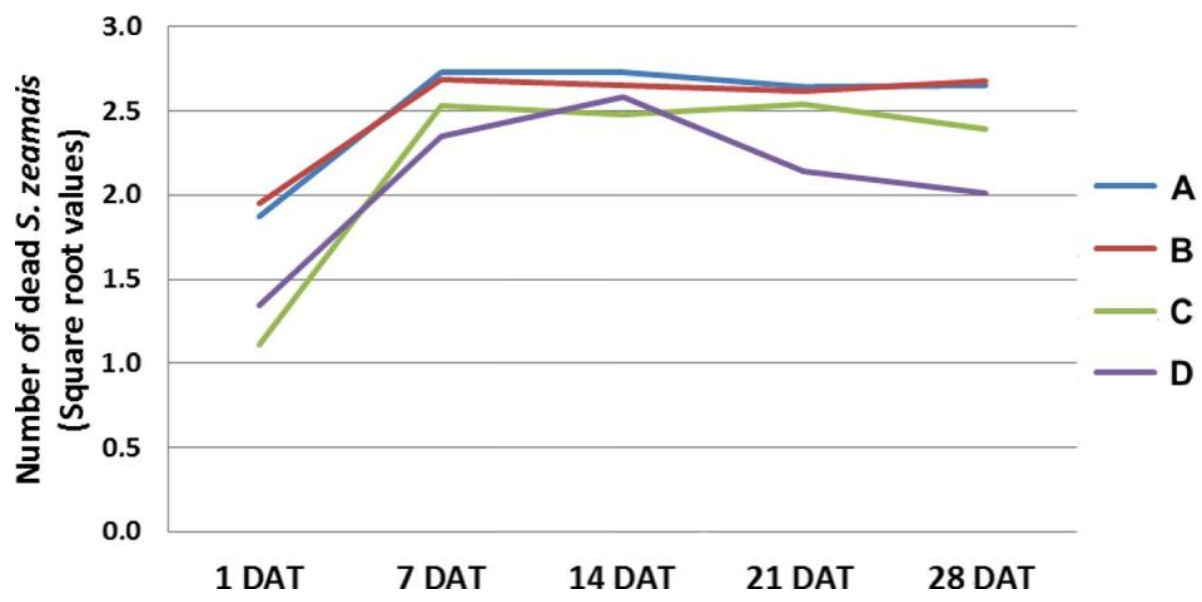

Fig. 2. Mean mortality of Sitophilus zeamais treated with botanicals at different days after treatment (DAT). A - Permethrin, B - Piper guineense, C - Jatropha curcas, D - Thevetia peruviana. 
Mean mortality of Sitophilus zeamais treated with Jathropha curcas powder in stored maize

The result of maize grains treated with Jatropha curcas powder for the control of Sitophilus zeamais is shown in Table 2. Analysis of variance of the data showed that mortality levels of adult S. zeamais in grains treated with Jatropha curcas dust differed significantly from each other. Irrespective of storage duration, batches treated with $10.0 \mathrm{~g}$ caused significantly higher total mortality of adult Sitophilus zeamais (2.75); this was followed by batches with $7.5 \mathrm{~g}$ (2.55). The control recorded no mortality. The effect of storage duration on the mortality of weevils increased significantly with increased storage duration, but there were no significant differences between adult $S$. zeamais mortality recorded at 7, 14, 21 and $28 \mathrm{DAT}$, except at $1 \mathrm{DAT}$.

Table 2. Mean mortality of Sitophilus zeamais treated with Jathropha curcas dust in stored maize.

\begin{tabular}{|l|c|c|c|c|c|c|}
\hline \multirow{2}{*}{ DAT } & \multicolumn{7}{|c|}{ Treatment Dosage (g) } \\
\cline { 2 - 7 } & $\mathbf{0}$ & $\mathbf{2 . 5}$ & $\mathbf{5 . 0}$ & $\mathbf{7 . 5}$ & $\mathbf{1 0 . 0}$ & Mean \\
\hline 1 & $0.0(0.71)$ & $0.25(0.84)$ & $1.25(1.31)$ & $0.50(1.31)$ & $2.50(1.73)$ & $0.90(1.11)^{\mathrm{b}}$ \\
\hline 7 & $0.0(0.71)$ & $8.25(2.1)$ & $8.50(2.99)$ & $9.50(2.99)$ & $7.25(2.78)$ & $6.75(2.53)^{\mathrm{a}}$ \\
\hline 14 & $0.0(0.71)$ & $8.50(2.95)$ & $8.25(2.95)$ & $9.25(2.49)$ & $9.25(3.12)$ & $6.60(2.48)^{\mathrm{a}}$ \\
\hline 21 & $0.0(0.71)$ & $7.25(2.78)$ & $6.25(2.78)$ & $8.50(3.04)$ & $9.75(3.20)$ & $6.85(2.54)^{\mathrm{a}}$ \\
\hline 28 & $0.0(0.71)$ & $6.00(2.55)$ & $8.75(2.55)$ & $7.75(2.91)$ & $8.00(2.90)$ & $5.95(2.39)^{\mathrm{a}}$ \\
\hline Mean & $0.0(0.71)^{\mathrm{b}}$ & $6.05(2.42)^{\mathrm{a}}$ & $8.00(2.55)^{\mathrm{a}}$ & $7.10(2.62)^{\mathrm{a}}$ & $7.35(2.75)^{\mathrm{a}}$ & - \\
\hline
\end{tabular}

DAT = Days After Treatment

Figures in parenthesis are square $\operatorname{root}(\sqrt{ } \mathbf{x}+0.5)$ values.

Means within a column/row followed by the same letter do not differ significantly from each other (P > 0.05; SAS, PROC GLM, SNK).

\section{Mean mortality of Sitophilus zeamais treated with Piper guineense in stored maize}

Table 3 shows the evaluation of Piper guineense against Sitophilus zeamais in stored maize. Batches of grains treated with $10.0 \mathrm{~g} P$. guineense recorded the highest total adult $S$. zeamais mortality (3.12), which was significantly different from the other treatments. Batches treated with 7.5, 5.0, and $2.5 \mathrm{~g}$ did not differ significantly, but were significantly higher than the untreated control.

There were no significant differences between adult $S$. zeamais mortality recorded at 7 , 14, 21 and 28 DAT, except at 1 DAT. 
Table 3. Mean mortality of Sitophilus zeamais treated with Piper guineense dust in stored maize.

\begin{tabular}{|l|c|c|c|c|c|c|}
\hline \multirow{2}{*}{ DAT } & \multicolumn{7}{|c|}{ Treatment Dosage (g) } \\
\cline { 2 - 7 } & $\mathbf{0}$ & $\mathbf{2 . 5}$ & $\mathbf{5 . 0}$ & $\mathbf{7 . 5}$ & $\mathbf{1 0 . 0}$ & Mean \\
\hline 1 & $0.0(0.71)$ & $4.00(2.12)$ & $1.25(1.99)$ & $3.50(2.17)$ & $7.25(2.78)$ & $3.80(1.95)^{\mathrm{b}}$ \\
\hline 7 & $0.0(0.71)$ & $9.50(3.16)$ & $8.50(3.20)$ & $9.75(3.12)$ & $10.00(3.24)$ & $7.70(2.69)^{\mathrm{a}}$ \\
\hline 14 & $0.0(0.71)$ & $9.25(3.12)$ & $8.25(3.20)$ & $9.75(3.12)$ & $9.25(3.12)$ & $7.50(2.65)^{\mathrm{a}}$ \\
\hline 21 & $0.0(0.71)$ & $8.00(2.91)$ & $6.25(3.08)$ & $9.00(3.08)$ & $10.00(3.24)$ & $7.30(2.62)^{\mathrm{a}}$ \\
\hline 28 & $0.0(0.71)$ & $9.00(3.08)$ & $8.75(3.20)$ & $9.75(3.20)$ & $9.75(3.20)$ & $7.65(2.68)^{\mathrm{a}}$ \\
\hline Mean & $0.0(0.71)^{\mathrm{c}}$ & $7.95(2.88)^{\mathrm{b}}$ & $8.35(2.94)^{\mathrm{b}}$ & $8.40(2.95)^{\mathrm{b}}$ & $9.25(3.12)^{\mathrm{a}}$ & - \\
\hline
\end{tabular}

DAT = Days After Treatment

Figures in parenthesis are square root $(\sqrt{ } \mathbf{x}+0.5)$ values.

Means within a column/row followed by the same letter do not differ significantly from each other (P > 0.05; SAS, PROC GLM, SNK).

\section{Mean mortality of Sitophilus zeamais treated with Thevetia peruviana in stored} maize

Significantly higher adult Sitophilus zeamais mortality was recorded on samples treated with higher dosages $(5.0,7.5$ and $10.0 \mathrm{~g})$ than with the lower doses $(2.5$ and $0.0 \mathrm{~g}$ ) (Table 4). Also treatments containing $2.5 \mathrm{~g}$ Thevetia peruviana seed dust caused significantly higher mortality than the untreated control.

Thevetia peruviana treated grains recorded significantly different Sitophilus zeamais mortality at the various storage periods (DAT). Significantly higher mortality was recorded at 14 DAT, followed by 7 DAT; the lowest was at 1 DAT (Table 4).

Table 4. Mean mortality of Sitophilus zeamais treated with Thevetia peruviana dust in stored maize.

\begin{tabular}{|l|c|c|c|c|c|c|}
\hline \multirow{2}{*}{ DAT } & \multicolumn{7}{|c|}{ Treatment Dosage (g) } \\
\cline { 2 - 7 } & $\mathbf{0}$ & $\mathbf{2 . 5}$ & $\mathbf{5 . 0}$ & $\mathbf{7 . 5}$ & $\mathbf{1 0 . 0}$ & Mean \\
\hline 1 & $0.0(0.71)$ & $0.50(0.96)$ & $3.75(2.06)$ & $1.75(1.48)$ & $1.75(1.49)$ & $1.55(1.34)^{\mathrm{d}}$ \\
\hline 7 & $0.0(0.71)$ & $4.75(2.29)$ & $7.75(2.87)$ & $8.75(3.04)$ & $8.50(2.99)$ & $5.95(2.38)^{\mathrm{b}}$ \\
\hline 14 & $0.0(0.71)$ & $6.75(2.99)$ & $9.75(3.20)$ & $9.25(3.12)$ & $9.75(3.20)$ & $7.10(2.58)^{\mathrm{a}}$ \\
\hline 21 & $0.0(0.71)$ & $4.75(3.20)$ & $5.50(2.44)$ & $6.00(2.54)$ & $7.00(2.74)$ & $4.65(2.14)^{\mathrm{c}}$ \\
\hline 28 & $0.0(0.71)$ & $4.00(2.74)$ & $4.50(2.22)$ & $5.25(2.38)$ & $6.50(2.64)$ & $4.05(2.01)^{\mathrm{c}}$ \\
\hline Mean & $0.0(0.71)^{\mathrm{c}}$ & $4.15(2.07)^{\mathrm{b}}$ & $6.25(2.56)^{\mathrm{a}}$ & $6.20(2.51)^{\mathrm{a}}$ & $6.70(2.61)^{\mathrm{a}}$ & - \\
\hline
\end{tabular}

DAT = Days After Treatment

Figures in parenthesis are square root $(\sqrt{ } \mathbf{x}+0.5)$ values.

Means within a column/row followed by the same letter do not differ significantly from each other (P > 0.05; SAS, PROC GLM, SNK). 
Mean mortality of Sitophilus zeamais treated with Permethrin dust in stored maize

All treatments containing Permethrin dust caused significantly higher total adult Sitophilus zeamais mortality than the untreated control. Mortality of adult S. zeamais was significantly higher in samples treated with higher dosages (7.5 and $10.0 \mathrm{~g}$ ) compared with the lower dosages (5.0, 2.5 and $0.0 \mathrm{~g}$ ) (Table 5).

Table 5. Mean mortality of Sitophilus zeamais treated with Permethrin dust in stored maize.

\begin{tabular}{|l|c|c|c|c|c|c|}
\hline \multirow{2}{*}{ DAT } & \multicolumn{7}{|c|}{ Treatment Dosage (g) } \\
\cline { 2 - 7 } & $\mathbf{0}$ & $\mathbf{2 . 5}$ & $\mathbf{5 . 0}$ & $\mathbf{7 . 5}$ & $\mathbf{1 0 . 0}$ & Mean \\
\hline 1 & $0.0(0.71)$ & $2.75(1.80)$ & $2.25(1.65)$ & $4.75(2.29)$ & $8.00(2.92)$ & $3.55(1.87)^{\mathrm{b}}$ \\
\hline 7 & $0.0(0.71)$ & $10.00(3.24)$ & $10.00(3.24)$ & $10.00(3.24)$ & $10.00(3.24)$ & $8.00(2.74)^{\mathrm{a}}$ \\
\hline 14 & $0.0(0.71)$ & $10.00(3.24)$ & $10.00(3.24)$ & $10.00(3.24)$ & $10.00(3.24)$ & $8.00(2.74)^{\mathrm{a}}$ \\
\hline 21 & $0.0(0.71)$ & $8.25(2.96)$ & $8.75(3.04)$ & $10.00(3.24)$ & $10.00(3.24)$ & $7.40(2.64)^{\mathrm{a}}$ \\
\hline 28 & $0.0(0.71)$ & $9.50(3.16)$ & $9.25(3.12)$ & $9.00(3.08)$ & $9.50(3.16)$ & $7.45(2.65)^{\mathrm{a}}$ \\
\hline Mean & $0.0(0.71)^{\mathrm{c}}$ & $8.10(2.88)^{\mathrm{b}}$ & $8.05(2.88)^{\mathrm{b}}$ & $8.75(3.02)^{\mathrm{ab}}$ & $9.50(3.16)^{\mathrm{a}}$ & - \\
\hline
\end{tabular}

DAT = Days After Treatment

Figures in parenthesis are square $\operatorname{root}\left(\sqrt{ }_{\mathbf{x}}+\mathbf{0 . 5}\right)$ values.

Means within a column/row followed by the same letter do not differ significantly from each other (P > 0.05; SAS, PROC GLM, SNK).

Table 6. Phytochemical analysis of the botanicals and Permethrin dust.

\begin{tabular}{|l|c|c|c|c|c|}
\hline Samples (Botanicals) & Alkaloids & Tannins & Flavonoids & Saponins & phenols \\
\hline Piper guineense & ++ & ++ & ++ & + & + \\
\hline Jatropha curcas & ++ & ++ & + & + & + \\
\hline Thevetia peruviana & + & - & + & - & + \\
\hline Permethrin dust & ++ & ++ & ++ & + & + \\
\hline
\end{tabular}

++ (high level), + (low level), - (absent)

\section{Determination of phytochemical composition of treatments}

The phytochemical composition of the treatments indicated that alkaloids were present at high levels (++) in Jatropha curcas, Piper guineense and Permethrin dust and at low levels $(+)$ in Thevetia peruviana. High levels of tannins were present (++) in Jatropha curcas, Piper guineense and Permethrin dust, whereas they were absent (-) in Thevetia peruviana. Flavonoids were present in high concentrations $(++)$ in Piper guineense and Permethrin dust, but in low ones (+) in Jatropha curcas and Thevetia peruviana. Saponins were present in low concentrations (+) in Jatropha curcas, Piper guineense and Permethrin 
dust, but absent (-) in Thevetia peruviana. Low levels of phenols were present (+) in all the plant seed dusts and Permethrin (Table 6).

\section{DISCUSSION}

The results of the study revealed that the botanical treatments tested significantly reduced the number of adult Sitophilus zeamais in maize stored for 28 DAT. The insecticidal activities of various plant parts and products on $S$. zeamais with similar trends have been reported by IVBIJARo (1983), COBBINAH \& APPIAH-KWARTENG (1989), OBENGOFORI et al. (1997), ARANNILEWA et al. (2006), ARAYA \& EMANA (2009) and EDELDUOK et al. (2012). ADEDIRE \& AJAYI (1996) recorded $100 \%$ mortality of $S$. zeamais treated with Capsicum frutescens L. 28 DAT on maize grains. This is comparable to the synthetic Permethrin as indicated by DANJumma et al. (2009). Similarly, recent studies by EDELDUOK et al. 2015 revealed that cotyledon powder of melon significantly reduced natality and oviposition of Sitophilus zeamais in storage while significantly increasing mortality.

It has also been shown that the efficacy of treatments increases with increasing dosage. This result is similar to the work done by UKEH et al. (2008), where 5 and $10 \mathrm{~g}$ powdered Piper guineense was significantly toxic to Sitophilus zeamais and suppressed $F_{1}$ progeny emergence compared to $1 \mathrm{~g}$ of powder and the control. This result is also in agreement with the observations of UDO (2005) and ASAWALAM et al. (2007), whose studies on plant spices demonstrated that a higher quantity of Piper guineense on Sitophilus zeamais caused significant mortality and also reduced the production of progeny. Studies on the insecticidal activity of Jatropha curcas have been reported by HABOU et al. (2011). The use of Thevetia peruviana fruits for suicide attempts has been reported in Sri Lanka and southern India (EDDLESTON et al. 1999). KHANAM et al. (2008) tested Sapium indicum WiLlD., Thevetia neriifolia JUSS. and Jatropha gossypifolia L. on Tribolium castaneum (HERBST, 1797) and T. confusum JACQUELIN DU VAL, 1861 in Bangladesh and found them to possess insecticidal properties.

Although the mode of action of these botanicals was not determined in this trial, the death of Sitophilus zeamais might have been caused by blockage of the spiracles leading to asphyxiation and/or the insect ingesting lethal doses of the treatment thus resulting in stomach poisoning. LAW-OGBOMO \& ENOBAKHARE (2007) and SimBARASHE et al. (2013) made similar observations. Odours from Piper guineense was reported to significantly repel adult Sitophilus zeamais (UKEH et al. 2010, AKINBULUMI et al. 2017).

The presence of alkaloids, flavonoids and phenols in these botanicals may be responsible for their bioactivity. This hypothesis had earlier been supported by LALE 
\& Alaga (2001), Nweze et al. (2004) and ChaIEB (2010). AKHTAR \& ISMAN (2004) also were of the opinion that the effectiveness of different plant materials on maize weevils may depend on several factors, such as chemical composition and maize weevil species susceptibility. The presence and level of secondary chemical metabolites may have contributed to the differences observed in the results. ARAYA \& EMANA (2009) reported that the insecticidal activities of the plant powders are variable and broad, and depend on different factors like the presence of bioactive chemicals in them. Although post-treated seed viability was not tested in this trial, OJIAKO \& KAYODE (2014) suggested that maize treated with botanicals had no negative effect on viability, and thus should be used as seeds for planting. However, OJIAKO et al. (2014) concluded that Jatropha curcas treated maize seeds should not be used for food on account of their containing poisonous alkaloids. The findings from this study give further credence to the insecticidal properties of the extracts from these locally available plants and could constitute a component of a maize weevil management programme.

\section{CONCLUSIONS}

1. Seed dusts of Piper guineense, Jatropha curcas and Thevetia peruviana significantly reduce the number of adult $S$. zeamais in stored maize.

2. Alkaloids, flavonoids and phenols were present in these botanicals and might be responsible for their bioactivity.

\section{REFERENCES}

ADEDIRE C.O., AJAYI T.S. 1996. Assessment of the insecticidal properties of some plant extracts as grain protectants against the maize weevil, Sitophilus zeamais MOTSCHULSKY. Nigerian Journal of Entomology 13(1): 93-101.

AKHTAR Y., ISMAN M.B. 2004. Comparative growth inhibitory and anti-feedant effects of plant extracts and pure allelochemicals on four phytophagous insect species. Journal of Applied Entomology 128(1): 32-38.

Akinbuluma M.D., Ewete K.F., Yeye E.O. 2017. Phytochemical investigations of Piper guineense seed extract and their effects on Sitophilus zeamais (Coleoptera: Curculionidae) on stored maize. Journal of Crop Protection 6(1): 45-52.

Arannilewa S.T., Ekrakene T., Akinneye J.O. 2006. Laboratory evaluation of four medicinal plants as protectants against the maize weevil, Sitophilus zeamais (МотsCH.). African Journal of Biotechnology 5(21): 2032-2036.

Araya G., Emana G. 2009. Evaluation of botanical plants powders against Zabrotes subfasciatus (BOHEMAN) (Coleoptera: Bruchidae) in stored haricot beans under laboratory condition. African Journal of Agricultural Research 6(10): 1073-1079. 
Asawalam E.F., Emosairue S.O., Ekeleme F., Wokocha R.C. 2007. Insecticidal Effects of Powdered Parts of Eight Nigerian Plant species Against Maize weevil, Sitophilus zeamais MotschulsKy (Coleoptera: Curculionidae). Electronic Journal of Environmental, Agricultural and Food Chemistry 6(11): 2526-2533.

ChaIEB I. 2010. Saponins as Insecticides. A Review. Tunisian Journal of Plant and Protection 5(1): $39-50$.

Cobbinah J.R., ApPiAh-Kwarteng J. 1989. Effects of some neem products on stored maize weevil, Sitophilus zeamais (MотSCH.). Insect Science and its Applications 10(1): 89-92.

Danjumma B.J., Majeed Q., Manga S.B., Yahaya A., Dike M.C., Bamaiya L. 2009. Effects of some plants powders in the control of Sitophilus zeamais (МотSCH.) (Coleoptera: Curculionidae) infestation on maize grains. American-Eurasian Journal of Scientific Research 4(4): 313-316.

Danloye A.A., Tesilim K.O., Negbenebor, H., Makanjuola W.A. 2008. Assessment of the efficacy of Actellic and Sumithion in protecting grains from infestation during storage. Journal of Entomology 5(1): 24-30.

Eddleston M., Ariaratnam C.A., Meyer W.P., Perera1 G., Kularatne A.M. Attapattu S., SHERIFF M.H.R., WARRELl D.A. 1999. Epidemic of self-poisoning with seeds of the yellow oleander tree (Thevetia peruviana) in northern Sri Lanka. Tropical Medicine and International Health 4(4): 266-273.

EdELduoK E.G., AKPABio E.E., Eyo J.E., EKPE E.N. 2015. Evaluation of the insecticidal activity of cotyledon powder of melon, Citrullus vulgaris SCHRAD against the maize weevil, Sitophilus zeamais MOTSCH. Journal of Biopesticides and Environment 1: 50-57.

EdELDUOK, E.G., AKPABIO, E.E., Eyo J.E., EKPE E.N. 2012. Bio-insecticidal potentials of testa powder of melon, Citrullus vulgaris SCHRAD for reducing infestation of maize grains by the maize weevil, Sitophilus zeamais MoTSCH. Journal of Biology, Agriculture and Healthcare 2(8): 13-17.

Gadzirayi C.T., Mutandwa E., Chikuvire T.J. 2006. Effectiveness of Maize Cob Powder in Controlling Weevils in Stored Maize Grain. African Studies Quarterly 8(4): 1-11. Internet: http://www.africa.ufl.edu/asq/v8/v8i4a1.htm

Goel G., Makkar H.P.S, Francis G., Becker K. 2007. Phorbol Esters: Structure, Biological Activity and Toxicity in Animals. International Journal of Toxicology 26(4): 279-288.

Greenberg S.M., Showler A.T., Liu T.X. 2005. Effects of neem-based insecticides on Beet armyworm (Lepidoptera: Noctuidae). Insect Science 12(1): 17-23.

Habou Z.A., Hadugui H., Mergeai G., Haubruge E., Toudou A., Verheggen F.J. 2011 Insecticidal effect of Jatropha curcas oil on the Aphid, Aphis fabae (Hemiptera: Aphididae) and on the main insect pests associated with cowpea (Vigna unguiculata) in Niger. Tropicultura 29(4): 225-229.

IsLAM E.F. 2006. Insecticidal and Repellent Properties of Piper guineense seed extract for the control of maize weevil, Sitophilus zeamais. Journal of Environment, Agriculture and Food Chemistry 5(3):1389-1394.

IVBIJARO M.F. 1983. Preservation of cowpea, Vigna unquiculata (L.)WALP with the neem seed, Azadirachta indica A. Juss. Protection Ecology 5(2): 177-182.

Kamatenesi-Mugisha M., Deng A.L., Ogendo J.O., Omolo E.O., Mihale M.J., Otim M., Buyungo J.P., BEFT P.K. 2008. Indigenous knowledge of field insect pests and their management around 
Lake Victoria basin in Uganda. African Journal of Environmental Science and Technology 2(8): 342-348.

Khanam L.M., Khan A. R., KhalequZzaman M., Rahman S.M. 2008. Effect of Sapium indicum, Thevetia neriifolia and Jatropha gossypifolia seed extract on the fecundity and fertility of Tribolium castaneum and Tribolium confusum. Bangladesh Journal of Sciences and Industrial Research 43(1): 55-56.

KubO I., NAKANISHI K. 1977. Chapter 11. Insect antifeedants and repellents from African plants. [in:] P.A. Hedin (ed.). Host Plants Resistance to Pests. American Chemical Society, Washington, D.C., $165-178$.

LALE N.E.S. 2002. Stored-product entomology and acarology in tropical Africa. Molepublications (Nig.) Ltd., Maiduguri, Nigeria.

LALE N.E.S. 2010. Inaugural Lecture Series No. 68: Stealthy thieves in homes and food stores University of Port Harcourt, Rivers State, Nigeria.

LALE N.E.S., Alaga K.A. 2001. Exploring the insecticidal, larvicidal repellent properties of Piper guineense (SCHUM and THONN) seed oil for the control of rust-red flour beetle Tribolium castaneum (HERBST) in stored pearl millet Pennisetum glaucum (L.) R. BR. Journal of Plant Diseases and Protection 108(3): 305-313.

Law-Ogbomo K.E., Enobakhare D.A. 2007. The use of leaf powders of Ocimum gratissimum and Vernonia amygladina for the management of Sitophilus oryzae (L.) in stored rice. Journal of Entomology 4(3): 253-257.

Martínez-Herrera J, Chel-Guerrero L, Martínez-Ayala A.L 2004. The nutritional potential of Mexican piñon (Jatropha curcas). Toxic and antinutritional factors. [in:] M. MuZQuIZ, G.D. Hill, C. Cuadrado, M.M. Pedrosa, C. Burbano (eds.) The fourth international workshop on antinutritional factors in legume seeds and oilseeds, Toledo, Spain, 8-10 March 2004. EAAP Scientific Series, Volume 110. Academic Publishers, Wageningen, 185-188.

NTONIFOR N.N., Monah I.M. 2001. Use of three species to protect stored maize against Sitophilus zeamais. Tropical Science 41(2): 74-77.

Nukenine E.N., Monglo B., Awason I., Ngamo L.S.T., Thuenguem F.F.N., NGassoum M.B. 2002. Farmers' perception on some aspects of maize production and infestation levels of stored maize by Sitophilus zeamais in the Ngaoundere region of Cameroon. Cameroon Journal of Biology and Biochemistry Science 12(1): 18-30.

Nweze E.I., OKAFOR J.I., NJOKU O. 2004. Antimicrobial activities of methanolic extracts of Trema guineensis (SCHUMm and ThORN) and Morinda lucida (BENTH) used in Nigeria. Bio-Research 2(1): $39-46$

Nwoкосна A.B., Agbagwa I.O., ОкоLi B.E. 2011.Comparative phytochemical screening of Jatropha species in the Niger Delta. Research Journal of Phytochemistry 5(2): 107-114.

OBENG-OFORI D., AMITEYE S. 2005. Efficacy of mixing vegetable oils with pirimphos-methyl against the maize weevil, Sitophilus zeamais MotsChULSKY in stored maize. Journal of Stored Product Research 41(1): 57-66.

Obeng-Ofori D., Reichmuth C.H., Benele J., Hassanali A. 1997. Biological activity of 1, 8 cineole, a major component of essential oil of Ocimum kenyense (AYOBANGIRA) against stored product beetles. Journal of Applied Entomology 121(4): 237-243. 
Ogunsina O.O., Olademeji M.O., LaJide L. 2011. Insecticidal action of hexane extracts of three plants against bean weevil, Callosobruchu maculatus (F.) and maize weevil, Sitophilus zeamais MotsCH. Journal of Entomology and Natural Environment 3(1): 23-28.

Ojiako F.O., Dialoke S.A., Ihejrika G.O., Ahuchaogu C.E., Iheaturueme H.I. 2014. Management of stored maize against Sitophilus zeamais Motschulsky (Coleoptera: Curculionidae) with the seed and root powders of Jatropha curcas (L.). International Journal of Agriculture and Rural Development (SAAT FUTO) 17(3): 1899-1904.

OJIAKO F.O., KAYODE R.M.O. 2014. Nutritional quality and consumer acceptability of cowpea seeds (Vigna unguiculata L. WALP) treated with natural and synthetic insecticides against bruchid infestation. Journal of Stored Products Research 56: 9-15.

Омотоso O.T. 2014. Evaluation of the powder of three medicinal botanicals in the control of maize weevil, Sitophilus zeamais MotschULSKY. Nature and Science 12(11): 184-190.

SAS [SAS InSTITUTE] 2001. The Statistical Analytical Systems for windows. Release 8.1 Cary. North Carolina, USA.

Simbarashe M., Chitamba J., Mutetwa B. 2013. Evaluation of Eucalyptus tereticornis, Tagetes minuta and Carica papaya as stored maize grain protectants against Sitophilus zeamais (МотSCH.) (Coleoptera: Curculionidae). Agriculture, Forestry and Fisheries 2(5): 196-201.

Toteja G.S., Mukherjee A., Diwakar S., Singh P., Saxena B. N, Sinha K.K. 2006. Aflatoxin B1 contamination of parboiled rice samples collected from different states of India: A multi-center study. Food Additive and Contamination 23(4): 411-414.

Trease G.E., Evans W.C. 1989. Pharmacognosy. $13^{\text {th }}$ Edition. Bailliere Tindale, London.

UDO I.O. 2005. Evaluation of the potential of some local spices as stored grain protectant against the maize weevil Sitophilus zeamais (МотsсH.) (Coleoptera: Curculiinidae) Journal of Applied Sciences and Environmental management 9(1): 165-168.

Ukeh D.A., Birkett M.A., Bruce T.J., Allan E.J., Pickett J.A., Luntz A. J. 2010. Behavioural responses of the maize weevil, Sitophilus zeamais, to host (stored-grain) and non-host plant volatiles. Pest Management Science 66(1): 44-50.

Ukeh D.A., Gabriel A.A., Emmanuel I.O. 2008. Toxicity and oviposition deterrent of Piper guineense (Piperaceae) and Monodora myristica (Annonaceae) against Sitophilus zeamais (MотSCH.) on stored maize. Journal of Entomology 5(4): 295-299.

Uygun U., Ozbey R., Koksel H. 2007. Residue level of malathion and fenithion and their metabolites in postharvest treated barley during storage and malting. Food Chemistry 100(3): 1165-1169.

Received: 2 March 2017

Accepted: 23 May 2017 